\title{
A Profile of Patients with Molar Pregnancy
}

\author{
Bhatt $\mathbf{R}^{\mathbf{1}}$, Rijal $\mathbf{P}^{\mathbf{1}}$, Pradhan $\mathrm{T}^{\mathbf{1}}$, Chhetri $\mathbf{S}^{\mathbf{1}}$, Rai $\mathbf{R}^{\mathbf{1}}$, Uprety $\mathbf{D}^{\mathbf{1}}$ \\ Department of Obstetrics and Gynecology, B.P. Koirala Institute of Health Sciences (BPKIHS), Dharan, Nepal.
}

Received: 29-Nov-2016; Accepted: 17-Dec-2016

\begin{abstract}
Aims: This study was done to determine the incidence, modes of presentation and prognosis of molar pregnancy at B. P. Koirala Institute of Health Sciences.

Methods: This was a prospective study done among patients with molar pregnancy admitted at BPKIHS from January 2010 to January 2011. The study was conducted after ethical clearance from Institutional Ethical Review Board of BPKIHS. Written informed consent was taken for enrollment in the study. Baseline information like age, address, race and patient's presenting complaints, period of gestation and serial serum beta human chorionic gonadotropin ( $\beta$ hCG) were collected and analyzed after entering in excel sheet.
\end{abstract}

Results: Total 48 cases of molar pregnancy were diagnosed during the study period. The incidence of molar pregnancy was found to be 5.58 per 1000 deliveries. The most common mode of presentation was per vaginal bleeding i.e. in $64.58 \%$ of cases Majority of the patients were in the age group of $20-34$ years $(62.5 \%)$. Mean time for normalization of $\beta$ hCG after suction evacuation was 10.19 weeks.

Conclusions: Molar pregnancy is a pregnancy related problem which most commonly presents with per vaginal bleeding during first and second trimester. Most of the patients are treated with suction and evacuation but some develop persistent gestational trophoblastic disease.

Keywords: $\beta$ hCG; molar pregnancy.

\section{INTRODUCTION}

Hydatidiform moles are abnormal conceptions with incidence of 1/500-1000 pregnancies. Complete moles are usually diploid and developmentally androgenic, demonstrating hydropic chorionic villi and trophoblastic hyperplasia. Partial moles are usually paternally derived triploid conceptions in which embryonic development occurs in association with trophoblastic hyperplasia.'Partial hydatidiform moles are characterized by chorionic villi of varying size with focal hydatidiform swelling, cavitations, trophoblastic hyperplasia, marked villous scalloping and prominent stromal trophoblastic inclusions. Complete hydatidiform moles exhibit characteristic swelling and trophoblastic hyperplasia and have propensity to malignancy. ${ }^{2}$

The classic presenting symptoms and findings of hydatidiform mole include vaginal bleeding, anemia, excessive uterine enlargement, hyperemesis gravidarum, hyperthyroidism, trophoblastic emboli and theca lutein cysts associated with remarkably elevated $\beta$ hCG titres. ${ }^{3,4}$

\section{CORRESPONDENCE}

Dr. Rabindra Dev Bhatt

Department of Obstetrics and Gynecology

BPKIHS, Dharan, Sunsari, Nepal

Email: rabindrabhatt364@gmail.com

Phone: +977-9842038782
After evacuation it should be ensured that $\beta$ hCG levels remain undetectable. If patients want to conceive, they are generally advised not to become pregnant again until after the first six months of follow up and are given reliable contraception. After spontaneous resolution, the patient is subsequently seen monthly for six months. ${ }^{5-7}$

Most gestational trophoblastic neoplasia (GTN) cases are diagnosed clinically using hormonal evidence of persistent trophoblastic tissue. Tissue is infrequently available for pathologic diagnosis. So GTN is diagnosed on the basis of rising $\beta$ hCG values or a persistent plateau of $\beta \mathrm{hCG}$ values for at least three weeks. ${ }^{8-13}$

Since BPKIHS is a tertiary care centre of Eastern Nepal, patients coming here represent the population of Eastern Nepal. The clinical profile of patients with molar pregnancy has not been studied in this area in past, this study was conducted to find out the the clinico-epidemiological profile of molar pregnancy in Eastern Nepal.

\section{METHODS}

This was a prospective study done among patients with molar pregnancy admitted at BPKIHS from January 2010 to January 2011. The study was 
conducted after ethical clearance from Institutional Ethical Review Board of BPKIHS. Written informed consent was taken for enrollment in the study. All cases of molar pregnancy attending Department of Obstetrics and Gynecology, BPKIHS from January 2010 to January 2011 were included in the study. Patients diagnosed on clinical or radiological or histopathology examinations were included. All of them were followed up with serum $\beta \mathrm{hCG}$ level at weekly interval. Once $\beta$ hCG was normal for three consecutive values, further follow up at monthly interval was done for six months. Those cases which could not be followed up for 6 months were not included in study. Data of the patients regarding personal details, presenting complaint and examination findings was entered in excel sheet. Outcome of treatment was recorded and findings at follow up visit were recorded. Time taken for $\beta$ hCG level to normalize was recorded. Data was analyzed by SPSS version 11.0 to determine the incidence, common modes of presentation, distribution among various age and ethnic groups and prognosis of patients using percentage, mean and range.

\section{RESULTS}

A total of 48 patients were taken for the study. The incidence of molar pregnancy was found to be 5.58 per 1000 deliveries (1/179 deliveries). Majority of the patients were in the age group of 20 to 34 years $(\mathrm{n}=30,62.5 \%)$. The mean age of the patients was 25.04 years, the youngest was 17 and the oldest was 48 years of age. Majority of patients belonged to Mongolian ethnic group ( $\mathrm{n}=26,54.2 \%)$. (Table 1)

Table 1. Socio demographic variables $(n=48)$.

\begin{tabular}{|lll|}
\hline Characteristics & Number & Percentage \\
\hline $\begin{array}{l}\text { Age group in years } \\
\quad<20\end{array}$ & 12 & 25 \\
\hline $20-35$ & 30 & 62.5 \\
$>35$ & 6 & 12.5 \\
Mean & & 25.04 \\
\hline $\begin{array}{l}\text { Occupation } \\
\text { Housewife }\end{array}$ & 45 & 93.75 \\
$\quad$ Shopkeeper & 2 & 4.17 \\
$\quad$ Teacher & 1 & 2.08 \\
Address & & \\
$\quad$ Sunsari & 22 & 45.83 \\
Dhankutta & 9 & 18.75 \\
$\quad$ Jhapa & 9 & 18.75 \\
Others & 8 & 16.67 \\
Race & & \\
Mongolian & 26 & 54.2 \\
\hline
\end{tabular}

\begin{tabular}{|lll|} 
Aryan & 22 & 45.8 \\
Religion & & \\
Hindu & 41 & 85.42 \\
Buddhist & 4 & 8.33 \\
Christian & 3 & 6.25 \\
\hline
\end{tabular}

The most common presenting complaint was vaginal bleeding $(n=31,64.58 \%)$. One patient $(2.08 \%)$ had history of passage of grape like vesicles and 10 $(20.83 \%)$ patients were asymptomatic and were diagnosed to have molar pregnancy during routine antenatal check up by ultrasonography. Half of the patients were primigravida and $12.5 \%$ of patients had history of irregular cycles. Mean gestational age at time of diagnosis was 12.92 weeks (range 8-26 weeks). $14.58 \%$ of patients had history of OCP use (Table 2).

Table 2. Modes of Presentation $(\mathrm{n}=48)$.

\begin{tabular}{|c|l|l|}
\hline & $\begin{array}{l}\text { Number } \\
\text { of patients }\end{array}$ & Percentage \\
\hline $\begin{array}{c}\text { Presenting complaint } \\
\text { Vaginal bleeding }\end{array}$ & 31 & 64.58 \\
Vomiting & 2 & 4.17 \\
Passage of grape & 1 & 2.08 \\
$\quad$ like vesicles & 2 & 4.17 \\
Pain abdomen & 2 & 4.17 \\
Fever & 10 & 20.83 \\
None & & \\
Obstetric & 23 & 47.91 \\
Primigravida & 25 & 42.09 \\
Multigravida & & \\
\hline Gestational age & 26 & 54.17 \\
\hline$\leq 13 w k s$ & 22 & 45.83 \\
\hline$>13 w k s$ & & \\
\hline
\end{tabular}

Nine $(18.75 \%)$ patients were anemic at the time of presentation (Table 3).On histopathological examination, 19 (39.58\%) patients had complete hydatidiform mole and $29(60.42 \%)$ had partial hydatidiform mole. During follow up, 18 (48.64\%) patients had normalization of $\beta$ hCG within eight weeks of suction evacuation. Mean time taken for normalization of $\beta$ hCG was 10.14 weeks (Table 4).

Table 3. Lab Investigations ( $\mathrm{n}=48)$.

\begin{tabular}{|llll|}
\hline & Categories & $\begin{array}{l}\text { No. of } \\
\text { patients }\end{array}$ & $\%$ \\
\hline Hemoglobin & $<10 \mathrm{~g} / \mathrm{dl}$ & 9 & 18.75 \\
& $\geq 10 \mathrm{~g} / \mathrm{dl}$ & 39 & 81.25 \\
Histopathology & complete mole & 19 & 39.58 \\
\cline { 2 - 4 } & partial mole & 29 & 60.42 \\
\hline
\end{tabular}

In two patients $(5.41 \%)$ hCG was persistently rising and were diagnosed to have persistent trophoblastic 
disease and were given single agent chemotherapy (Methotrexate and Folinic acid) and responded to treatment.

Table 4. $\beta$ hCG follow up ( $n=48)$.

\begin{tabular}{|cl|}
\hline $\begin{array}{l}\text { Normalisation of } \boldsymbol{\beta h C G} \\
\text { (weeks) }\end{array}$ & $\begin{array}{l}\text { Number of patients } \\
(\%)\end{array}$ \\
\hline$\leq 8$ & $28(58.33 \%)$ \\
$>8$ & $20(41.67 \%)$ \\
Mean & 10.19 weeks \\
\hline
\end{tabular}

DISCUSSION

In this study, the incidence of molar pregnancy was found to be 5.58 per 1000 deliveries which is less than that of the study done in Institute of Medicine, Kathmandu, Nepal by Soma H. et $\mathrm{al}^{14}$ in which incidence was found to be 8.04 per 1000 deliveries. But the incidence in this study is more than that of the study done in Northern England by Tham et $\mathrm{al}^{15}$ and Paropakar Maternity and Women's hospital, Kathmandu by Thapa et $\mathrm{al}^{16}$ in which it was found to be one per 771 and one per 276 live births respectively.

In this study most of the patients of molar pregnancy were of age group 20 to 34 years which is not consistent with the study done by Tham et $\mathrm{al}^{15}$ in Northern England in which molar pregnancy was common among extremes of age that is, below 15 years and above 35 years. Most of the patients were Mongolian (54.2\%) which may be due to predominance of this ethnic group in this part of country. The most common mode of presentation was per vaginal bleeding $(64.58 \%)$ in this study which is similar $(77.0 \%)$ to the study done by Lindholm et al. ${ }^{17}$

The mean gestational age at the time of diagnosis was found to be 12.92 weeks which is similar to the finding of the study done by Soto-Wright et $\mathrm{a}^{18}(11.8$ weeks). The uterine size was more than the gestational age in $37.58 \%$ in this study which is similar to SotoWright et $\mathrm{al}^{18}(28.0 \%)$. In this study, $18.75 \%$ patients were anemic at the time of presentation which is significantly more than the $4 \%$ rate shown by by Soto-Wright et al. ${ }^{18}$

In this study, $39.58 \%$ patients had complete moles and $60.42 \%$ had partial moles on histopathological examination which is similar to the study by GiwaOsagie et $\mathrm{al}^{19}$ in which $39.0 \%$ had complete moles and $61.0 \%$ had partial moles. The mean time for $\beta$ hCG to become normal was 10.19 weeks which is slightly more than the 8 weeks shown in the study done by Bagshawe et $\mathrm{al}^{3}$. In two patients $(5.41 \%)$ $\beta$ hCG was persistently rising and were diagnosed to have persistent trophoblastic disease and were given single agent chemotherapy (Methotrexate and Folinic acid) and responded to treatment.

\section{CONCLUSIONS}

Molar pregnancy is a pregnancy related problem which most commonly presents with per vaginal bleeding during first and second trimester. Early ultrasonography has detected most of the molar pregnancy earlier reducing the burden of complications due to late presentation. Most of the patients are treated with suction and evacuation but some develop persistent gestational trophoblastic disease. So follow up with serum $\beta$ hCG at regular intervals should be done in all cases.

\section{DISCLOSURE}

The authors report no conflicts of interest in this work. No violation of human rights and safety.

Funding: Nil

\section{REFERENCES}

1. Sebire NJ, Foskett M, Fisher RA, Rees H, Seckl M, Newlands E. Risk of partial and complete hydatidiform molar pregnancy in relation to maternal age. Br J Obstet Gynecol. 2002;109:99-102.

2. Berek J, Novak E, editors. Berek \& Novak's gynecology. 14th ed. Philadelphia: Lippincott Williams \& Wilkins; 2007.

3. Bagshawe KD, Dent $\mathbf{J}$, Webb J. Hydatidiform mole in England and Wales. Lancet 1986;2:673-7.

4. Wake N, Tanaka K, Chapman V, Matsui S, Sandberg AA. Chromosomes and cellular origin of choriocarcinoma. Cancer Research. 1981;41:3137-43.

5. Curry SL, Schlaerth JB, Kohorn EI, Boyce JB, Gore H, Twiggs LB et al. Hormonal contraception and trophoblastic sequelae after hydatidiform mole. Am J Obstet Gynecol. 1989;160:805-11.

6. Soper JT, Mutch DG, Schink JC. Diagnosis and treatment of gestational trophoblastic disease: ACOG Practice Bulletin No. 53. Gynecol Oncol. 2004;93:575-85

7. Lavie I, Rao GG, Castrillon DH, Miller DS, Schorge JO. Duration of human chorionic gonadotropin surveillance for partial hydatidiform moles. Am J Obstet Gynecol. 2005;192:1362-4.

8. Schorge J, Williams J, editors. Williams gynecology. 2nd ed. New York: McGraw-Hill Medical; 2008.

9. Feltmate CM, Bartorfi J, Fulop V, Goldstein DP, Doszpod J, Berkowitz RS. Human chorionic gonadotropin follow-up in 
patients with molar pregnancy: a time for reevaluation. Obstet Gynecol. 2003;101:732-6.

10. Pisal N, Tidy J, Hancock B. Gestational trophoblastic disease: is intensive follow up essential in all women? BJOG. 2004;111:1449-51.

11. Batorf J, Vegh G, Szepesi J, Szigetvari I, Doszpod J, Fulop V How long should patients be followed after molar pregnancy? Analysis of serum hCG follow-up data. Eur J Obstet Gynecol Reprod Biol. 2004;112:95-7.

12. Niemann I, Vejerslev LO, Frøding L, Blaakær J, Maroun LL, Hansen ES et. Al. Gestational trophoblastic diseases clinical guidelines for diagnosis, treatment, follow-up, and counseling. Dan Med J. 2015 Nov; 62(11):A50-82.

13. Biscaro A, Braga A, Berkowitz RS. Rev Bras. Diagnosis, classification and treatment of gestational trophoblastic Neoplasia .Ginecol Obstet. 2015; 37(1):42-51.

14. Soma H, Malla D, Dali SM. Clinical experience with trophoblastic diseases in Nepal. Gan To Kagaku Ryoho. 1989;16(4):1577-81.
15. Tham BWL, Everard J E, Tidy J A, Drew D, Hancock BW. Gestational trophoblastic disease in the Asian population of Northern England and North Wales. Br J Obstet Gynecol.2003;110:555-9.

16. Thapa K, Shrestha M, Sharma S, Pandey S. Trend of complete Hydatidiform mole. J Nepal Med Assoc. 2010;49(1):10-3.

17. Lindholm H, Flam F. The diagnosis of molar pregnancy by sonography and gross morphology. Acta Obstet Gynecol Scand. 1999;78:6-9.

18. Soto-Wright V, Bernstein M, Goldstein DP, Berkowitz RS. The changing clinical presentation of complete molar pregnancy. Obstet Gynecol. 1995;86(5):775-9.

19. Giwa-Osagie MO, Okwerekwu G. Epidemiology of molar pregnancies in Northern Ireland. Int J Gynaecol Obstet. 1999;66:175-8 